\title{
The Environmental Effects of Policy Change in the West African Savanna: Resettlement, Structural Adjustment and Conservation in Western Mali
}

\author{
Dolores Koenig and Tiéman Diarra 1
}

The development of African agriculture has been an explicit goal of both colonial and postindependence governments. Yet quite different initiatives were implemented as development theories and political goals changed. As multiple researchers have shown, many of these attempts to improve African agriculture foundered in one way or another, leading to more new analyses, new policies, and new projects. New emphases and fashions in development did not always simply replace the old; new initiatives often coexisted with older programs whose inspiration was quite different. This could lead to inconsistency and even contradiction among different policies and programs at a single time and place. In the case of externally funded development initiatives, changes in development theory and practice occurred among donor countries as well as within developing country governments.

A perspective on policy, which explicitly assumes heterogeneous structures and interests within contemporary states, has been inspired by the work of political scientists like J.Bayart (1995), who showed how multiple decision-making centers within the French government led to contradictory approaches to French foreign policy in Africa. It also draws upon studies documenting the diverse interests of elite groups in developing countries and varying levels of elite cohesion (M.Bratton and N.van de Walle 1992; N.Chazan 1992).

This paper uses such an approach to understand the range of observed consequences in a single situation in the West African savannah. Elsewhere, one of us looked more directly at the bureaucratic level, analyzing competition among Malian government organizations (D.Koenig 1997). Here we turn to the utility of this perspective for

1. Research in 1993-94 was funded by National Science Foundation Grant SBR-9309513; earlier research during project implementation was funded by USAID Manantali Resettlement Project 6250955 through the Institute for Development Anthropology. We would like to thank Dr. Klena Sanogo, Director of the Institut des Sciences Humaines in Mali for his support of this project, as well as the other members of the research team: Yaouaga Félix Koné, Fatoumata Maiga, and Hadiza Djibo Traoré. We would also like to thank USAID Bamako and the Malian Direction Nationale de l'Hydraulique et de l'Energie for their assistance, especially Mahamadou Sidibé, Mamadou Coulibaly, Richard Gold, and Djibril Diallo. Idrissa Bagayoko, Carol Hart, and Lucy Mize all provided important logistical support. Alice Willard and Della McMillan provided useful comments on earlier drafts. The authors retain responsibility for the views expressed herein.Map reprinted by permission of Westview Press. 
illuminating the reasons behind a particular local problem, the rapidly decreasing agricultural productivity of the Bafing River valley of western Mali. In this zone, some 10,000 people, mostly ethnic Malinke, were involuntarily displaced in 1986 and 1987 by the construction of the Manantali dam. We suggest in this paper that the quick decline in agricultural productivity can only adequately be understood in reference to two simultaneous but politically separate and distinct policy initiatives: large-scale river basin programs and structural adjustment. These two efforts evolved from different approaches to development theory and practice, yet their simultaneous implementation meant that the production possibilities of the residents of Manantali were affected by both.

River basin development programs are consistent with an approach to development that privileges state intervention and central planning. They also emphasize large-scale infrastructure and potential industrial growth as a means to development. The focus is often on irrigated as opposed to rain-fed agriculture. The river basin development organization relevant here was the Organisation pour la Mise en Valeur du Fleuve Sénégal (OMVS, Senegal River Basin Authority), a three-country (Mali, Mauritania, Senegal) effort to "develop" the Senegal River basin. It is an international public organization whose employees are international civil servants; the Conference of Heads of State and Government (of the member states) is its governing body (B.Godana 1985). The idea of regulating the Senegal for purposes of electricity production, irrigation, and navigation was already present in the colonial government in the late 1940s, and postindependence states began to meet and draw up plans in the early 1960s, although the OMVS itself was not created until 1972 (B.Godana 1985:127, 218-19, 221). ${ }^{2}$ Implementation of its goals came even later, as funding had to be secured for its two major pieces of infrastructure: a high dam at Manantali in southwest Mali on the Bafing-a tributary of the Senegal-and a salt-retention barrage at Diama, near the mouth of the river in Senegal.

Manantali itself would receive few direct benefits from the river basin program; in particular, most irrigation was planned for much further downstream. Located at the 1,100 mm long-term isohyet (M.Traoré 1980), rain-fed agriculture predominated at Manantali and would continue to do so. The main effects on the local population were the involuntary resettlement of people living in the future reservoir area.

The structural adjustment approach came later; the World Bank (1981) document, Accelerated Development in Sub-Saharan Africa, marked its formal appearance. A complete structural-adjustment package included multiple government reforms, all generally meant to encourage African countries to move toward more "liberal" economies with market-oriented economic policies, more efficient use of prices, and greater openness to international trade (S.O'Brien 1991). In its emphasis on the role of private-sector markets rather than state-sponsored central planning, structural adjustment came from policy thinking that was diametrically opposed to the earlier initiatives such as river basin development.

Governments did not simply get rid of all existing programs when new development approaches such as structural adjustment appeared. Although some might be replaced, others were simply left to continue. J.Guyer (1991) noted that Nigeria kept a seemingly contradictory embargo on grain imports while undertaking its structural adjustment

2. Although the source of the Senegal river is in Guinea, and Guinea participated in early discussions about the development of the Senegal basin, it did not participate in the creation of the OMVS. Guinea is permitted to join, but it has not done so (B.Godana 1985). 
program, whereas D.Wilcock's (1995) case studies of Morocco, Senegal, and Kenya showed that previous policy initiatives remained important despite new structural adjustment programs. Sometimes, as in the policies toward Senegalese rice, these appeared to be contradictory to structural-adjustment intentions. Within Mali, the World Bank continued to include in its portfolio financing for the Office du Niger, a parastatal irrigation scheme of dubious economic and agricultural return (M.Kamuanga 1982; World Bank 1994). ${ }^{3}$

In Manantali, dam construction plans begun years earlier continued even as structuraladjustment initiatives began to encourage private-sector activities. There was no intrinsic relationship between market privatization and involuntary resettlement, the two major local effects of the larger policy initiatives, but they did occur simultaneously. As this paper will show, their interaction furthered one goal of both: stimulating agricultural and economic growth. The economic changes had negative environmental effects, especially deforestation and decreased soil fertility. These latter, however, in turn negatively affected the potential for future agricultural development. We suggest that the interaction increased the environmental problems beyond what they likely would have been had only one of these larger policies been in place.

The paper proceeds historically, in three major sections. We begin with the era just prior to structural adjustment and resettlement, the late 1970s and early 1980s. During this period, the presence of government initiatives was relatively low, and a sparse population made extensive use of abundant natural resources. By the 1970s, relatively well funded rural-development efforts offered residents new options, but did not close off previously existing ones. The second section of the paper looks at the changing policy context of the mid-1980s, focusing on the two initiatives - involuntary resettlement and structural adjustment - that substantially changed the natural and political environment. These new efforts offered new opportunities but also closed off some previous options. This section includes a discussion of the major points analysts have raised concerning the environmental consequences of each of the policy initiatives. The third section turns to the effects of the simultaneous implementation of these policies in the Manantali zone in the early 1990s. Together they brought economic benefits, but contributed to environmental decline. Farmers tried innovatively to deal with the new context, but incurred new social costs in doing so. The conclusion offers suggestions for both theory and practice.

Before turning to the analysis, we discuss the data sources used. Because this paper covers multiple time periods, there are many data sources, not all of similar approach or quality.

3. Although the belief in central planning was shared by many donors and developing countries in the 1980s, the 1980s push for structural adjustment came particularly from the donors, with the World Bank and the International Monetary Fund playing leading roles. The fact that many development country governments felt coerced into adopting structural-adjustment programs may account in part for the fact that older programs did not always change. We believe, however, that resistance to the constraints of international organizations was not the only reason. In particular, both bureaucratic inertia and the competition between different government organizations to "own" particular programs would appear to be important as well. Further analysis of the reasons for inconsistent policies merits its own study and is beyond the scope of this paper. 


\section{Data Sources and Method}

As we will discuss in more detail below, the relative isolation of the Bafing valley was one of its most striking features prior to dam construction. Hence, it was little studied and to the best of our knowledge, no focused work was done on the zone before the planning stage of dam construction. Then, one part of the OMVS feasibility study concerned the potential population resettlement, both resettling populations and the areas to which they were likely to move (Groupement Manantali 1978). Just prior to the move, the United Nations Development Programme (UNDP) funded another set of studies of the resettlement zones, including another study of the social and economic characteristics of the resettling population (IER 1984). Both of these studies focused on contemporary culture and economics. The US Agency for International Development (USAID), which did not contribute any funding for dam construction, decided to finance the resettlement and both these studies were used by the planning team to design a project (USAID 1984).

Once the resettlement began, more studies were undertaken to verify population characteristics and to track change. The USAID-funded project, called the PRM (Projet pour la Réinstallation des Populations de Manantali, or Manantali Resettlement Project) and a part of Mali's Direction Nationale de l'Hydraulique et de l'Energie (DNHE), did its own census of the population of potential resettlers, its physical structures and its goods, in 1985. The USAID project also funded the Institute for Development Anthropology to provide social-science advice to the PRM; Koenig served as senior advisor and made regular short-term trips to the project area between 1986 and 1989. The DNHE, with USAID funding, contracted with the Malian Institut des Sciences Humaines (ISH) for a series of studies from 1986 through 1990 on the short-term effects of the resettlement on economic and social organization in the zone. Diarra served as head of this team in its later years. ${ }^{4}$

The data gathered through these studies was both ethnographic and quantitative. The PRM created a sample of 70 households that it planned to monitor over the resettlement years, although it never made much use of these data. The ISH studies systematically followed 50 households; these raw data were destroyed in civil disturbances in Bamako in 1991 after the reports were written. Again these studies mostly concentrated on contemporary characteristics although the ISH team also consulted available documents to clarify some of the Bafing valley's history.

Because this resettlement project was one of the biggest projects in the zone, it continued to attract the attention of scholars. A dissertation on the project was written by another anthropologist funded through the Institut for Development Anthropology (C.Grimm 1991). Several Malian social and natural scientists also wrote dissertations, one of which proved especially useful here (A.Traore 1995). We returned to the zone as well in 1993-94 with funding from the National Science Foundation to look at social and economic effects of the resettlement over a longer period.

The 1993-94 study had both quantitative and qualitative aspects. We created a combined sample of 113 households, integrating the 50 ISH households with the 70 others monitored by the PRM; some had been in both original samples, and a few had left the zone. Because the ideal household held collective fields managed by its head to provide

4. The original team leader, Maximin Samaké, drowned in the Manantali reservoir while carrying out research. 
necessary food and cash, the team interviewed all the managers of collective fields in the 113 households. A total of $99 \%$ of these households had collective fields. Most households also had individual fields managed by other men and women to gain supplementary income or to meet deficits in collective production. We interviewed up to one man and one woman individual field owner in each household, which resulted in a sample of 153 individual field owners, 107 women and 46 men. ${ }^{5}$ In addition, a sample of individuals chosen to include people of different genders and statuses was interviewed in depth about economic changes. Individual interviews were complemented by separate group discussions with village leaders, younger men, and women, as well as by participant observation.

This paper draws upon all these sources to follow changes over the different periods. To be sure, data quality varied widely from one study to another, and because virtually none of the earlier data sets had been preserved, we were usually obliged to use aggregate figures for comparisons over the different periods. The one exception was that we were able to return to the original 1985 PRM census to compare sample households directly in 1985 and 1993-94. Data on the period prior to the resettlement comes from the earlier studies as well as from historical work done by ISH (e.g. M.Samaké et al. 1987) and in the dissertations (e.g., A.Traoré 1995).

\section{Before the Resettlement: Late 1970s and Early 1980s}

The most striking feature of the Manantali zone prior to the resettlement was its physical isolation, at least partly a function of its hilly terrain. The rocky and lateritic hills limited arable farming as well as accessibility; only an estimated 55 percent of the land was cultivable (PIRT 1986:121,122). Nevertheless, there were a variety of natural resources in different environmental niches and the relatively sparse population (about 5/ $\mathrm{km} 2$ in the arrondissement as a whole in the late 1970s in contrast to an average $15.3 / \mathrm{km} 2$ in the more developed areas in southeastern Mali [Groupement Manantali 1978:1; TAMS 1983]) relied upon relatively extensive use of abundant natural resources to make their living.

Although affected by state activities in its environs, the people of the Bafing valley, mostly ethnic Malinke, were not considered a central part of the, precolonial, colonial, or independent states, at least until dam construction began. The zone was difficult to penetrate because of its hilly terrain, had less than optimal agricultural potential because of its many lateritic areas, and had few people to swell armies or ranks of salaried workers. All states need to make choices about resource deployment; they rarely if ever control equally all areas to which they lay claim. Manantali appears to have rarely been a priority and state control was usually only partial. Nevertheless, the zone was hardly untouched, and some of its characteristics were responses to state activities elsewhere.

5. The ideal division of labor required household heads to provide the staple grain while women provided ingredients for the complementary sauce. Household heads gave fields to women so they could grow these ingredients, as otherwise, the cultural division of labor would have obliged them to provide money. In contrast, decisions about whether male household members should work only the collective field or whether these men should be permitted individual fields involved complicated calculations that depended upon family size, family values, and the personalities of the members. For further information on these decisions see T.Diarra et al. (1995) and D.Koenigé et al. (1995). 
The Malinke population of the Bafing zone traced itself back to a son of Tirimakan Traoré, a war leader under Sundiata Keita in the thirteenth century Mali empire. This man's three sons were considered the ancestors of the three major contemporary Bafing clans (A.Traoré 1995:26). Upon their arrival, the Malinke clans evidently forced current residents to move elsewhere or accept a lower status in the political hierarchy (A.Traoré 1995). Although these Malinke settlers came from a state and delineated a political hierarchy among themselves, no centralized polity appears to have developed here. Rather, the move into the difficult terrain of the Bafing may have been an attempt to move away from the major war routes, reducing the likelihood of being raided (G.Brasseur 1968:215; cf. P.Richards 1983). Nonetheless, the area appears to have been subject to raids by various rulers searching for slaves (M.Samaké et al. 1986:6). One precolonial response was the concentration of the population in a limited number of fortified villages (A.Traoré 1995).

In the mid-1800s, the Bafing valley was devastated by the attacks of the Islamic Toucouleur leader, El Hadj Oumar Tall, who had a base at Koundian, some $30 \mathrm{~km}$ to the west of Manantali. To get to his goal, the Bambara kingdom of Segou, hundreds of kilometers to the east, Oumar had to cross the Bafing valley and the Manding plateau. He placed one of his followers, Niamou Keita, in charge of the conquest of the Bafing and from 1848 to 1855, Niamou led some 127 campaigns against the local Malinke (M.Samaké et al. 1986:9). Once the Toucouleur army had moved through the Bafing, most of it then moved into more agriculturally productive and powerful areas. The locals remembered this period as one of great insecurity, where members of the same family often found themselves fighting one another on different sides of the conflict. Some people dated their move into fortress villages to this period (A.Traoré 1995); others appear to have been taken as slaves (D.Robinson 1985).

When the Toucouleur invasion was over, the late 19th century brought news of another destructive conqueror, Samory Touré. The Bafing, not surprisingly, saw the arrival of French colonialism as the possibility to live in relative security (A.Traoré 1995:31). People began to leave their compact fortress villages and create dispersed settlements in the countryside. Of 42 major villages, locals reported that 16 were created in the latter half of the nineteenth century and 8 during the early 1900s (Groupement Manantali 1978:A51). Yet French colonial involvement in the Bafing went little beyond this. Like the precolonial states before them, they concentrated activities in more strategic areas; in the case of French West Africa, this meant the most accessible zones close to railways (C.Coquery-Vidrovitch 1986; C.Wrigley 1986). Peanut cultivation did arrive in the Bafing in the late 1800 s after the French introduced peanuts to villages along the railroad, some 60-100 km distant (M.Samaké et al. 1987:29), but, lacking roads, there was little direct movement into the Bafing's forested hills. The zone saw no major infrastructure and no significant development efforts in the colonial period (M.Samaké et al. 1987).

Independence did not bring much more activity, despite explicit government goals for national development. The national government created an arrondissement ${ }^{6}$ in the Bafing village of Bamafele in 1962 and built primary schools in 1960 and 1964, one on each side of the river. Yet by the mid-1970s, schools were still small, and there was no post office, no Forest Service representative, no major market, nor any regular public transport into or out

6. At that time, the arrondissement was the basic unit of local administration. It is now being replaced by the commune rurale. 
of the zone (Groupement Manantali 1978:A41,A45). Only the agricultural extension service, represented by the Opération de Développement Integré pour les Productions Arachidière et Céréalière (ODIPAC) ${ }^{7}$ had a major presence in the Manantali zone in the 1970s.

The lack of development around all but the rail corridor was common to much of western Mali (its First Region). The northern part of the First Region (around the towns of Kayes, Nioro and Yelimane), bordering Senegal and Mauritania, was much drier than the south and became a classic labor reserve. Many of its residents emigrated, domestically and internationally. In contrast, in the southern part of the First Region, population densities were relatively low, and rainfall was relatively abundant. Many, including the Malinke of the Bafing, turned to production strategies based on local natural resources. ${ }^{8}$

In sum, prior to the resettlement, the Malinke of the Bafing had a relatively selfsufficient economic system, and although the Malian state and private-sector markets were present, they were not very active. People were expected to pay taxes, and they sold some produce, but they continued to provide most of their own subsistence as well. Some people migrated; some people got educated; there were some contacts with major cities in Bamako and overseas. But compared to other areas in Mali, both development initiatives and out-migration were relatively low. The attitude of people toward state and market institutions appears to have been neither simple acceptance nor simple resistance. Having suffered from the activities of state systems for hundreds of years, people were wary of them, but they did not so much question the legitimacy of any given state as attempt to negotiate a situation with state representatives that would increase potential benefits and decrease potential disadvantages. We look first at the 1970s production strategies and then at the effects of state initiatives at that time.

\section{The Natural Environment}

Through the 1970s and the early 1980s, the combination of low population density and inaccessibility led to the use of a complex set of ecological niches for different production purposes. Although sometimes considered "traditional" land-use patterns and production strategies, these choices should be seen as a response to the existing environmental and political context (P.Richards 1983).

The Bafing valley upstream from the potential dam site was a relatively narrow river valley surrounded by hills and cliffs. Most settlement was concentrated along the river, as people were drawn by its year-round water sources and the arable land on its banks. They

7. By 1993, ODIPAC had changed its name to ODIMO (Opération de Développement Integré du Mali Ouest). Earlier names included the OACV (Opération Arachide et Cultures Vivrières), the best known of several. In 1996, the organization was disbanded. We will refer to it throughout the paper as ODIPAC, the name it had at the time of the resettlement.

8. As in other parts of southern Mali, average annual rainfall has decreased since the Sahel drought, from the $1100 \mathrm{~mm}$ long-term to $985 \mathrm{~mm}$ for the 6 seasons from 1988-89 through 1993-94. Unlike the eastern half of southern Mali, however, the Bafing saw few drought refugees from more northern areas. Presumably remittances sent by migrant workers to residents of the northern First Region attenuated the effects of the drought by allowing people to buy food (DNAS 1985). In any case, the lack of accessibility in the southern First Region made it relatively unattractive. The main response

of the Bafing residents to the drought seems to have been the increased adoption of short-cycle crop varieties. 
used the plains there to cultivate annual rainy-season crops, mostly food grains and peanuts, and for irrigated gardens when the rains were over. Irrigation technology for the gardens was rudimentary (water carried in buckets from river to fields), but some farmers earned quite large sums from irrigated tobacco sold to private-sector merchants. Vegetables, as well as fruit trees grown in low-lying areas, increased the variety in local diets. Many people also did some fishing.

To complement limited agricultural land close to the river, the Bafingois used several complementary environmental niches. Many cultivated outer bush fields of grains and peanuts in the pockets of arable land on the hills and plateaux. Although dispersed, these pockets were sufficiently abundant that relatively long fallow periods were common (M.Samaké et al. 1986). Some of these fields could be reached daily from the villages, but others required the creation of agricultural hamlets where farmers spent the rainy season. For example, the largest village in the zone had 14 seasonal hamlets and few people remained in the central "mother village" at the height of the farming season (C.Grimm 1991). Few hamlets grew to become year-round villages because water was available only seasonally on the plateaux.

In addition, Bafingois used uncultivable forest areas for gathering foods and medicines as well as for hunting, and as herbaceous zones for livestock pasture. Residents sent domestic herds of cattle, sheep, and goats to nearby hills to find food under only minimal supervision. They protected useful tree species, such as nere (Parkia biglobosa), shea (Butyrospermum paradoxum baobab (Adansonia digitata) and dugura (Cordyla pinnata).

Malian law did not recognize private land ownership in most rural areas (GRM 1987), yet locals generally distinguished a collective village territory that included not only cultivated areas, but also fallowed fields, pasture, and bush areas for hunting, gathering, and fishing (IER 1984:79). However, people also claimed that the bush "belonged to no one", 9 and some areas were simultaneously exploited by neighboring villages (A.Traoré 1995). The combination of low population densities, extensive land use, and cultivation of annual crops meant that issues of land ownership were generally not very important.

\section{The Policy Context of the 1970s: ODIPAC and Central Planning}

Although government programs were slow to reach the Bafing, some of them did so. Mali's postindependence governments of the 1960s and 1970s believed that centralized control of the economy was essential for economic growth and development, as did many other African governments at this time. Two themes inspired agricultural policy: national food self-sufficiency and a belief that agricultural income could fund other national investments. During the 1960s, Modibo Keita's socialist government tried many different ways to bring this about, but the only successful initiative was the French-funded Compagnie Malienne de Développement des Textiles (CMDT). Keita eventually tried to use the CMDT as a model for creating other regional rural development organizations, but was ousted in a 1968 coup by Moussa Traoré before he could do so. ${ }^{10}$ Traoré retained the

9. Translations from French and Malinke are ours.

10. Moussa Traoré remained in power until he was deposed by another coup in 1991 . 
CMDT model however, creating a number of Opérations de Développement Rural (ODRs, or Rural Development Operations).

Over time, each major agricultural zone in the country came to be covered by an ODR that stressed the production of a few crops, one of which was often a major cash earner such as cotton or peanuts. These organizations made few attempts to change local patterns of land and labor allocation, but affected production options through their provision of credit, inputs, and technology, and through control of product commercialization networks. ODRs used their control over crop sales to set standard producer prices that allowed them to recoup credit, support their own activities, and tax agricultural production. Contemporary analysts criticized the ODR structures for deepening inequities between urban residents and rural producers as well as for their lack of flexible response to changing environmental and ecological conditions (Y.Kebé 1981; C.Steedman et al. 1976), yet ODR activities also brought guaranteed markets and increased incomes to a broad base of middle-income farmers (W.Jones 1976; D.Koenig 1986).

Although each ODR was meant to have administrative and financial autonomy, none was financially self-sufficient, so each depended on one or several international donors (SATEC 1984,1985). Through the mid-1970s and early 1980s (i.e., until the advent of structural adjustment), the lack of economic self-sufficiency of these organizations was not necessarily problematic, as states expected to subsidize national institutions. Mali's own orientation toward central economic planning and national control by means of integrated rural development programs was supported by foreign donors.

The level of donor support to development programs was, furthermore, increased after the early 1970s when the first Sahel drought brought the region to international attention. As C.Somerville (1986:34) remarked, "To donors and recipients alike, it was apparent that the Sahel would need more than short-term relief in order to recover." The importance of long-term development over emergency relief was reflected in the amount of money put into the two activities. The UN Office for Emergency Operations in Africa tracked donor pledges of US $\$ 396.8$ billion for emergency relief to deal with the 1982-1985 Sahel drought (C.Somerville 1986:40-41). In contrast, in the single year of 1982, the region received US $\$ 1.513$ billion in development assistance funds (C.Somerville 1986:179). In line with the development ideologies of the time, many donors supported centrally planned projects targeting long-term rural growth in the belief that these would attack the root causes of economic stagnation. Integrated rural development programs that had started from a concern to increase agricultural production but grew to include other components (e.g., health, community development, and literacy) became particularly popular. Mali saw foreign assistance funds grow from a relatively low US \$21 million in 1970 to US \$118 million in 1974 and US \$145 million in 1975 (World Bank 1981). By 1980, aid receipts were US\$ 267 million (World Bank 1989:293). Although many of these development initiatives did not achieve their goals, they reflected both donor and national beliefs in the efficacy of planning and large-scale development projects. ODIPAC's initiatives in Manantali during the 1970s and early 1980s reflected this trend toward increased funding of integrated rural development initiatives, with increased support from international donors.

Created in 1967 in a national push to expand peanut cultivation for international export, ODIPAC considered itself an integrated rural development project by the early 1980 s, when it had entered ancillary activities such as functional literacy and the creation of village associations. It also was able to expand its geographic scope with the increased financing it received, and ODIPAC was active in Manantali by the late 1970s, despite its 
isolation. To increase productivity, ODIPAC encouraged the adoption of improved peanut varieties, fertilizers and other inputs, and animal traction, all of which it provided on credit. ODIPAC brought peanut-buying teams on trucks to six centralized sales points in the Bafing on roads it had helped to build. Eight functional literacy centers were created in Manantali villages. ODIPAC representatives became the primary link between local populations and state institutions, and ODIPAC's intervention also opened the isolated zone to private-sector activities, as merchants took advantage of ODIPAC routes to come and sell other goods during peanut-buying season (Groupement Manantali 1978). People responded to the greater presence of the Malian state instrumentally. They were willing to take advantage of what they saw as the benefits of this penetration, but tried to mitigate the perceived disadvantages of it. They increased their peanut production, which became an important source of income. They also took ODIPAC credit to get inputs and equipment. In the late 1970s, at the height of ODIPAC activity, 52 percent of farmers reported using fertilizers, 27 percent seed disinfectants, and 60 percent selected seeds (Groupement Manantali 1978:A49). The 1985 pre-resettlement census found that 42 percent of the 113 sample households had at least some equipment, including 40 plows, 46 multipurpose tool frames, 71 seeders and 5 carts.

Participation in ODIPAC activities did not transform the basic production strategies of the zone, however. Because both land and labor were sufficient, farmers were not forced to move resources out of other significant agricultural and nonagricultural activities to gain what they saw as the benefits of participation.

Their attitude toward credit reflected this strategy. People readily took credit when it was available, but were not inclined to repay. ODIPAC agents were either unwilling or unable to coerce repayment, and were sometimes even unwilling to invoke the simple sanction of refusing to grant further credit. Local people apparently saw this as a situation in which they could profit from the state. ${ }^{11}$ Thirty million Malian francs (US $\$ 37,220$ ) were outstanding in 1983; despite efforts to encourage repayment, there were still 12 million CFA francs (US \$29,850)unpaid in 1985-6 (M.Samaké et al. 1987:29). ${ }^{12}$ Farmers bought machinery and inputs on credit when they could, but when credit became tighter, as it did when the world price of peanuts fell in 1981, they ceased to do so. Input use declined noticeably between 1978 and 1982 (IER 1984:110), but this did not pose much of a problem for the Bafingois. They depended on these for good peanut production only, not for other components of their economic strategy. People even had other ways to earn cash through the sale of irrigated tobacco or fruit in the private sector. What ODIPAC had offered was an addition to the portfolio of resources available to people, primarily an increased opportunity for cash incomes by adding one more option to the diverse production possibilities presented by the varied ecology of the natural environment. The changing policy context of the mid-1980s was soon to change that economic terrain.

11. An analysis of why debt collection was not a priority is beyond the scope of this paper. It would require analysis of the internal bureaucracy of ODIPAC as well as its relationship to donors.

12. In 1984, the Malian currency was changed from the Malian franc (FM) to the CFA franc (FCFA), a currency shared by members of the West African Monetary Union. In 1983, 806 FM equalled US \$1.00, whereas in late 1985 , the exchange rate was 402 FCFA to US $\$ 1.00$. 


\section{The Changing Policy Context}

The 1980s saw several new policy initiatives. The Sahelian droughts of the 1970s and 1980s brought a renewed emphasis on environmental conservation, whereas structural adjustment brought economic liberalization and privatization. Manantali, on a tributary of the Senegal, and the site of the high dam to control flooding, was also affected by the OMVS development plans. Those living in the area that would become its reservoir had to be resettled.

\section{Environmental Conservation}

The Malian government had concerns about potential deforestation and desertification since at least the 1970s drought, if not before. It tried to discourage extensive cultivation, including both bush-fallow and shifting systems, and encourage intensification through what it called "sedentarization" of agriculture, a move toward more continuous cultivation and decreased clearing of new fields, particularly from forest areas. In the mid-1980s, new Malian laws mandated a number of conservation efforts, including taxes on new land clearing, interdiction of brush fires in forests and fallow, and requirements to use improved fuel-efficient stoves (DNEF 1986). Conservation efforts were supported by a variety of donors and programs (e.g. W.van Campen et al. 1988). Even with donor support, however, there were not enough funds to undertake all the planned environmental conservation initiatives. Moreover, other policy initiatives undermined some of these efforts.

\section{Structural Adjustment}

As discussed above, the major policy initiative of the 1980s was structural adjustment. In the Malian context, the primary changes came from the movement away from the central control of the economy desired by the national government toward greater reliance on market forces of supply and demand. The literature on the effects of structural adjustment has been diverse and abundant. We cannot do justice to it, but concentrate on a few sources that describe the local effects of the major rural initiative in Mali: privatization of aspects of agricultural development organizations.

Privatization efforts were intended to increase production and commercialization among farmers by stimulating demand for crops, especially export crops (A.Duncan and J.Howell 1992). This strategy may have hurt some of the poorest, as the rural poor were often net consumers who sold food when prices were lowest only to buy when prices were high. They also often lacked the resources to take advantage of new opportunities (J.Due 1991; A.Duncan and J.Howell 1992). Others, however, were able to enter new productive and commercial activities made available by adjustment programs. For example, in Nigeria, poorer women found new jobs as laborers on grain farms, whereas women farmers began to cultivate vegetables for sale; their success led to increased use of equipment and hired male labor (J.Guyer 1991). In Kenya, growth in livestock markets following structural adjustment led to higher prices for cattle and rising standards of living for Orma pastoralists (J.Ensminger 1991). In Puebla, Mexico, women started many new businesses, including stores, market stalls, and hairdressing; people generally believed that they had better lives than in earlier years (C.Gladwin 1995).

Although the economic effects of privatization have been positive for some people, studies of the effects of privatization on environmental sustainability have more 
commonly suggested negative results, although J.Greenberg (1997) noted that many of the impacts of structural adjustment on rural environments and their populations remain poorly documented. Nevertheless, there is evidence that structural adjustment in Africa has meant a decline in credit for and access to fertilizers and other inputs. As these inputs became more expensive in many places, farmers used them less, and the potential for soil degradation became greater. Farmers "mined" the soils, using them until all fertility was gone, and then moved on to clear new areas (C.Gladwin 1991; D.McMillan et al. 1998; T.Reardon et al. 1995). Although fertilizers are not a panacea for environmental problems and overuse can lead to new forms of environmental degradation, they are an important complement to organic methods for maintaining soil fertility among the rural poor in Africa (C.Gladwin 1991). Even in places where structural adjustment has had some positive economic impacts, the existing research leads us to expect a tension between its economic and environmental impacts.

In Manantali, one of the most obvious effects of structural adjustment was the effort to privatize the input and equipment provision and commercialization functions of the ODRs, although it occurred only gradually. As ODIPAC's donor funding decreased throughout the 1980s, the agency ceased providing credit to farmers for equipment or inputs and moved into and out of other activities in a more arbitrary fashion. It bought peanuts during some years, but not others. Even after it no longer gave credit and had reduced input sales, Dutch aid allowed it to buy a supply of fertilizers and other inputs, which it sold for cash in the early 1990s. This stock was abruptly depleted by 1994, putting an end to ODIPAC's input provision activities. If structural adjustment were the only major initiative, we would expect that over time Manantali would have experienced tension between economic and environmental effects. However, it also had to deal with the impacts of dam construction and resettlement.

\section{Involuntary Resettlement}

In contrast to structural adjustment, which may stimulate economic growth, dam construction and involuntary resettlement have generally had negative impacts on both the economy and environment for resettlers. The negative environmental effects are most evident. Reservoirs created by dams often flood some of the most productive alluvial lands, including rich flood plains with good agricultural land, lush forests and rich animal habitats. People often relocate to reservoir perimeters, almost always less fertile (P.Charest 1982; E.Colson 1971; A.Hall 1994; A.Wali 1993). In addition, resettlement usually implies more people settled on fewer resources, so that people must intensify resource use to maintain their living standards. The problem appears to be particularly acute for those groups that, prior to resettlement, had made extensive use of common property resources such as farmland, pasture, or forests (M.Cernea 1996; D.Koenig and T.Diarra 1996).

In addition, involuntary resettlement has often had negative economic impacts on resettled groups. Farmers lose the land that they had used to make their living, and rarely is replacement land sufficient to continue the kind of agricultural system that existed prior to resettlement (V.Adu-Aryee 1993; V.Lassailly-Jacob 1996). Nor do nonagricultural jobs easily replace land-based income strategies (K.Robinson 1986; M.Cernea 1996). Thus resettlers often find themselves with both insufficient land and nonagricultural economic opportunities. To be sure, dam construction itself offers jobs, but these are short-lived, and locals, who often lack the specialized training for skilled positions, often end up with the least remunerated and most ephemeral of jobs (P.Charest 1982; K.Robinson 1986). 
New job opportunities may appear postresettlement, linked to spontaneous development around the new infrastructure, e.g., fishing on the reservoir and associated fish-processing activities or other industries that make use of electricity. These are often too specialized to provide many opportunities for resettlers (M.Fofana et al. 1992). When resettlers have benefited from jobs created following relocation, this has often been linked to the independent, generalized growth of the national and regional economy (U.Mustanoja and K.Mustanoja 1993). Localized economic booms in resettlement areas may lead to further environmental degradation, however, as people haphazardly clear land for ranching, farming, or logging (A.Wali 1993; D.McMillan et al. 1998).

In response to these social science findings and to prevent impoverishment, donors, especially the World Bank, have created policies that require development programs for those affected by displacement-causing infrastructure development (M.Cernea 1988; 1991; T.Scudder 1981;1991). Although these policies were not yet current when the Manantali resettlement was planned in 1983, the Malian government and USAID used recent findings to help the Manantali Resettlement Project reach its goal to "relocate the people with the least disruption possible in their standard of living" (USAID 1984:14). However, some of the PRM's plans for resettler economic development depended on the continuation of government programs subsequently disbanded because of structural adjustment initiatives. The next section looks at the combined impact of these policy changes on the residents of the Manantali zone.

\section{After Resettlement and Structural Adjustment}

In the early 1990s, structural adjustment changes continued and were followed by democratization, which culminated in 1992 in multiparty elections and a new president: Alpha Oumar Konare. The resettlement project had finished. Manantali town, which had grown to some 15,000 residents at the height of dam construction in the mid-1980s, saw its population decline. The zone did not return to its preproject isolation, however. The 90$\mathrm{km}$ road built by the construction company to connect Manantali and the major railway stop at Mahina remained; regular transport service brought outsiders in and Bafing residents out. Because of easier access, the national government and ancillary organizations maintained a greater presence in the zone than they had 20 years earlier.

To get access to roads, markets and new organizations, the vast majority of the residents $(85 \%)$ had decided to move downstream from the dam site, to the northwest (Map 1). Increased settlement density coupled with the new infrastructure led to significantly different environmental conditions. ${ }^{13}$ This paper concentrates on those people who settled downstream, looking at the changing economic context, the growth in ecological pressures, and people's strategies for dealing with the new economic and physical environment.

13. The 15 percent of the population remaining upstream continued to live in a very sparsely populated zone with abundant natural resources, but little access to either roads or markets. For more information see T.Diarra et al. (1995). 


\section{New Economic Opportunities}

The zone downstream from the dam saw significant economic growth, primarily in the commercial sector. The initial impetus for greater commercialization came from the road built by the dam construction company in the early 1980s. It allowed locals to sell produce more easily and outside traders more opportunities to come in. The greater monetarization linked to the presence of large numbers of wage workers during the construction phase also accustomed locals to greater reliance on cash transactions. This did not disappear when construction was over and workers left. Rather, commerce continued to grow in new ways, spurred by the privatization aspects of structural adjustment.

Involvement of resettlers in this growth was helped along by certain aspects of the resettlement project. Because increased participation and choice were believed to improve resettlement outcomes, the project was designed with these in mind (D.Koenig 1988b; Y.Konate 1993). Thus, the PRM let the relocatees exercise their choice to move close to the dam site and roads. Although the PRM attempted to dissuade some of them, pointing out the potential environmental problems associated with more dense settlement, it eventually decided that it would be imprudent to overrule local choice, as long as site selection conformed to the published criteria of access to certain amounts of land and water. Despite the land shortages they later faced, these villages did indeed have some of the best economic opportunities.

Structural adjustment had its own particular effects. The guaranteed market for peanuts disappeared when ODIPAC no longer purchased them for industrial processing and export. Yet peanuts had never been only an export crop; there also was a large domestic market among consumers who cooked with peanut oil and peanut butter. Urban-based private traders, who had always existed to some degree alongside ODIPAC, expanded their activities and continued to buy peanuts from Manantali farmers. Although peanut production fell during the years directly after the resettlement (1986-87 and 1987-88), ${ }^{14}$ it increased again, substantially, by 1988-89, even though qualitative evidence from our study suggested that people grew fewer peanuts than at the height of ODIPAC activity in the late 1970s.

Peanut wholesaling was not restricted to intermediaries from outside the region. Some local individuals and groups of young men bought peanuts in villages to sell in the most accessible rail station market, Mahina. When in Mahina, some of them bought local necessities, including grains, to sell in their villages. Qualitative data suggest that the increase in the number of sellers offered consumers more options and better prices than before the resettlement when a few large-scale merchants had monopolized local sales. Several of the latter were among the most negative about the economic effects of the resettlement. They lost substantial trading businesses because of the increased competition they faced from other locals entering commerce.

Agricultural producers had also begun to try to take advantage of new crops for domestic urban markets. Seventeen percent of collective field owners in our sample, 24 percent of male individual field owners and 6.5 percent of female field owners had adopted new crops. Many tried "European" vegetables such as lettuce, cabbage, and carrots, as

14. Malian agricultural seasons generally run from clearing and planting in May and June until harvesting and sales through the following January; hence they are usually referenced by the two calendar years they cover. The heaviest rains come between July and October. 
well as sweet cassava, which urban Malians often eat as a snack. Some women also began to grow more rice than they had in their old homes. A few men began to sell fruits (e.g., bananas, mangoes). Others looked for niche markets. One local man came to be known as Mr. Cucumber because he specialized in cucumber cultivation and local sales.

The greater access to markets also made it easier for local artisans to purchase raw materials and to find clientele, spurring increased sales. Blacksmiths in particular benefited from privatization as they increased production and sales of plows and their spare parts, peanut threshers, and other agricultural equipment. Male leather workers also increased sales, the increased openness of the zone enabled them to migrate more easily to gold-mining areas where they could sell leather charms designed to bring good luck to miners.

The increased ease with which outside traders could enter the zone, and the growing desire of locals to commercialize their products led to the expansion of local weekly markets. Before resettlement, there was only one not very active local market among the Bafing villages. Dam construction brought a daily market to Manantali town, which continued after the resettlement, albeit on a smaller scale than at the height of construction. The Bafing zone itself grew to have three weekly markets, and the increased commercial activity reinvigorated two existing markets just to the north. Thus, by the 1990s, people had access to five weekly markets, one each day from Wednesday through Sunday. Although many large-scale traders were outsiders who came to buy produce or sell manufactured goods, the markets also stimulated commercial activity among locals. Women in particular became active participants. A few became specialized traders, entering new product lines. Some took advantage of the local markets to provision themselves and set up small stores in their villages, whereas others began to sell new processed foods, e.g., wheat flour cakes and biscuits in addition to the traditional millet ones.

Desires to increase production for sale led people to search for improved technologies. Farmers turned to what they knew well: agricultural equipment, draft animals, and inputs. Equipment (plows, multipurpose tool frames, seeders) and animals were easily available in private markets but inputs were not. Because animals and equipment were locally produced, and sales relied on existing market networks, private sector merchants appear to have moved effortlessly into their provision as ODIPAC moved out. Many Manantali relocatees used a part of their cash compensation to buy equipment, and aggregate numbers of owners, pieces, and users all increased from 1985 through 1994. The rate of equipment ownership increased from 42 percent of sample households in 1985 to 55 percent in 1993. During the same periods the numbers of plows owned increased by 35 percent (from 40 in 1985 to 54 in 1993), and the number of multipurpose tool frames by 17 percent (from 46 to 54). The number of carts almost tripled (from 5 to 14). As more households owned equipment, it became easier to use it, even if an individual did not own any. Among owners of collective fields, 67 percent (66 of 99) used equipment; among male owners of individual fields, 54 percent ( 25 of 46), and among women field owners, 38 percent (41 of 107). Many of those who borrowed equipment used kinship networks for access and were not required to pay. In the case of equipment and animals, structural adjustment appears to have removed some barriers to a commercial system already in place.

However, merchants did not move as easily into provision of agricultural inputs, especially fertilizers and seed disinfectants, a pattern found in other parts of Africa as well (A.Duncan and J.Howell 1992). In Mali, private circuits of agricultural input provision 
have arisen only very slowly, in a few commodities (e.g., pesticides), and mostly around big cities (J.Bingen et al. 1993; W.McConnell et al. 1994). Only farmers in the cotton zones continued to have easy access to inputs because the CMDT continued to facilitate access despite structural adjustment. Distributors mentioned that it was easier to sell inputs to a few large users (like extension agencies) rather than to a large number of small private sellers (J.Bingen et al. 1993). Clearly the latter course would require wholesalers to do more marketing and training of secondary vendors. As noted above, provision of inputs through ODIPAC had stopped by the early 1990s. Private merchants did not take over sales of fertilizer and other inputs when ODIPAC moved out, and no other local institution had begun to sell them. One key technology to increase productivity was thus missing: the means to maintain or raise soil fertility. Lack of access to inputs became a significant impediment to intensification, pushing people to increase agricultural production through extensive cultivation of greater land areas. We discuss the impacts of this in the following section.

In sum, although the economic effects of structural adjustment and the resettlement were uneven, both our data and the population's own perceptions suggest that, on balance, they led to improved standards of living for much of the resettler population. People were clearly enthusiastic about the markets and the increased commercialization. Although they recognized that money passed through their hands more quickly than it had prior to resettlement, many counted increased commercialization as the single positive benefit of dam construction and resettlement. At the height of dam construction, outside traders may have earned disproportionate benefits, but many of them left when most of the workers did. Since then, opportunities for trade and benefits from greater commercialization were available to a broad base of people, many of whom had earlier been deprived of market access because of the zone's isolation. In particular, the growth in private sector activity meant that some individuals in most households could earn money to purchase basic necessities. In contrast to the past, when people had few options besides foraging when hunger struck, they now could buy food when they faced shortages. Some 49 percent of households bought at least some cereal grains at the beginning of the 1993-94 agricultural season when their own stores had been depleted.

The literature on structural adjustment has tended to focus on increased export crop production, yet most of the growth at Manantali came from expanded production for domestic, mostly urban, markets. The privatization and liberalization of commercial networks encouraged traders to bring into the open and expand activities that had been pursued clandestinely in times of greater national control. The dam construction and resettlement projects, through road building, removed the other major barrier to commercial activity: inaccessibility. Even though the resettlement project contained only a minor economic development component, locals were able to benefit from a local economic boom created by the joint effects of privatization and increased market access. Because the increased commercial activity came primarily from domestic market growth, many activities to satisfy demand were based on the development of existing agricultural and artisanal production strategies and trade networks. Locals could build on their existing knowledge and were not closed out of new activities as they might have been if the increased activity had been new technologies or skills.

In the case of Manantali, each of the two policy initiatives reinforced the opportunities for economic growth brought by the other one, leading to more growth than would have been possible had only one occurred. Despite the changes, however, economic growth in the zone remained primarily based on agricultural products, their transformation, and 
services to growers. Continued growth would likely require even further increases in agricultural production. For these, people needed more resources, but national policies also made it difficult for them to get the resources to increase production sustainably. We turn to this problem in the following section.

\section{Environmental Effects}

Environmental problems resulted primarily from the increasing pressure on land resources for agriculture. The resettlement project can be considered the primary cause since it allocated insufficient land for both farm and nonagricultural activities. Structural adjustment also played a role, however, as it made agricultural intensification more difficult. Privatization not only made access to fertilizers more problematic but also discouraged the creation of new public agencies to work on alternative ways to intensify and achieve environmentally sustainable agriculture. Mali's national policy of increasing land and soil conservation became less important than either resettlement or structural adjustment, and was not strong enough to affect these policies.

The PRM design team was aware of earlier studies (e.g., T.Scudder 1981) showing that previous resettlement schemes had consistently distributed insufficient land. For example, projects often ignored women's plots or allotted set amounts of land per household, ignoring variation in household size. To deal with both these problems the PRM decided to vary household land allocations with household size and to count all active workers, men and women. As it quickly became evident that it was difficult to distinguish the inactive from active workers, all censused individuals between the ages of 8 and 59 were counted for land allocation purposes. Despite these attempts at improvement, the amount of land was still insufficient, mostly because planners underestimated the amount of land used by farmers in their old sites while they overestimated the amount available in the new ones.

In part, this was because planners failed to appreciate the production strategies of the 1970s, where residents made use of a great range of resources. They recognized that people carried out some of these activities, but they did not pay sufficient attention to the resources needed for them. In particular, they simply assumed that there would be more than enough land available. As the environmental assessment in the project plan noted, the UNDP-funded study "estimated the resettlement zones to cover an area of 97,200 hectares of which some 1,095 will be needed for village structures and 5,900 for cultivation of crops, leaving 90,200 for fallow fields and pasturage which is about 25 times more than the minimum area estimated as necessary for the resettlement effort" (USAID 1984: Annex 7.9:3). It is not clear where the total figure of 97,200 ha came from, but it accounted neither for the ecological characteristics of the land (whether it had the capacity to sustain the proposed activities) nor its sociopolitical ones (whether others had existing claims upon it).

The livestock situation most clearly illustrated the lack of attention to noncrop resources. The numbers owned were underestimated while the pasture and water available for them in the new sites were overestimated. Feasibility studies seriously underestimated the numbers of livestock as compared to the numbers reported in the PRM census just one year later: an average of 3 cattle per household in the former vs. 10.4 in the latter; 2 sheep vs. 4; and 1 goat vs. 2.8 (IER 1984:148). Moreover livestock numbers grew even more as people used cash compensation from the resettlement project and wage earning to buy animals. In our sample, cattle herd size increased by 53 percent $(1,175$ to 1,803$)$ from 1985 to 1989 and sheep and goat ownership went up by 95 percent (from 760 to 1,483). 
Not surprisingly, people found it difficult to get sufficient pasture and water in the new sites. Project assumptions that both would be abundantly available as the conditions were thought to be ecologically similar in new and old villages were simply wrong (USAID 1984, Annex 7.6:4; Annex 7.2.4:10). Because many villages wanted sites close to the road and the dam, village sites were closer to one another than in the old sites, decreasing pasture corridors between them considerably. Herds had to move through villages to get from the river on one side of the village to hilly pasture on the other. This led to increased complaints about animal depredations of crops. People sent their animals farther away, particularly to the hills behind the villages, leading to decreased surveillance and more lost animals. The presence of the new lake also changed wildlife movements, and villagers reported increased attacks on livestock by lions. The end result was a significant decline in livestock numbers between 1989 and 1993. By 1993, the sample households owned 661 cattle, only slightly more than half their 1985 numbers. Numbers of sheep and goats fell to 376, less than half their 1985 numbers. Although some had sold animals to meet food needs, people said that the greatest losses were due to epidemics and lack of pasture and water. Disease was almost surely increased by poor nutrition and by increased proximity which facilitated transmission.

As local population density increased, forests were cleared and people lost access to wild resources, particularly to the hunted and gathered foods that had supplemented diets in the old village sites. Finally, people also lost possibilities for irrigated agriculture, since new villages were located away from the river. This decision was motivated by good intentions to keep people at some distance from known riverine breeding sites of the black fly, the onchocerciasis vector (USAID 1984:Annex 7.1:6)-but it forced people to dig shallow wells if they wanted to continue to grow crops that needed supplemental water. ${ }^{15}$ The project plan had recommended placing village sites in zones where people could dig artesian wells to increase access to water for irrigation (USAID 1984: Annex 7.2.4:19), but the need to implement the project quickly led the PRM to concentrate on only a few criteria in site selection, e.g., drinking water and rainfed land (Y.Konate 1993). With few exceptions, villages found it difficult to dig artesian wells because of sandy soil that caused cave-ins or because of shallow bedrock.

Because land quantity and quality were insufficient to sustain the variety of activities people had undertaken prior to resettlement, they concentrated more of their energies on rainfed agriculture. Moreover, the economic growth of the zone meant that many people wanted to increase agricultural production, particularly new crops for new markets. Increased access to agricultural equipment also encouraged them to increase land areas. They needed more farm land than they had used before the resettlement, yet planners had not only underestimated new needs, but even the amount of land needed if the old system were to continue as it was, i.e., the land under cultivation and in fallow in the late 1970s and 1980s. To be sure, planning had begun with a relatively large figure, based on early studies suggesting that each active worker cultivated approximately 1.2 ha in rainfed crops. Estimating that each farm required an equal amount of fallow, a proposed total of 2.4 ha per active worker would be needed if people were to continue a similar subsistence strategy (Groupement Manantali 1978:A-14;C-5). Initial planning for the USAID-funded resettlement project began with this figure in mind. As the project implementation period

15. The project provided villages with deep wells with pumps for drinking water, but these were insufficient to irrigate more than a small number of gardens. 
approached, however, new studies were carried out to make the earlier figures more precise. The economic study suggested that the cultivated area was more along the lines of 0.8 ha per active worker, with 50 to 80 percent additional land needed for fallow, or a total of 1.2 to 1.44 ha per active worker (IER 1984:136), only 50 to 60 percent of the initial 2.4 ha figure. Because this study appeared more up-to-date, planners decreased estimates and used the smaller figure to calculate land allocations. This figure, however, appeared to be based on general knowledge of Malian agriculture, not on specific studies of the situation in the Bafing. Because the Bafing farming system was more extensive than the systems of many of its neighbors, with more land in fallow for longer periods, this estimate was in error.

Planners also overestimated the amount of land available for farms, because they did not consider sufficiently the ramifications of local land-tenure politics. The PRM decided not to allocate or clear fallow in the belief that people could easily get access to additional land in subsequent years because the resettlement area seemed to have much unoccupied land (USAID 1984, Annex 7.6:5). They believed that there would be "much more cultivable land" because downstream cliffs and hills were farther from the river (USAID 1984, Annex 7.4:16). Although land was not privately owned in these areas, community tenure systems were working institutions, and one community or another had rights over most "unused" land. Host villages had participated in the site selection of resettling villages and had formally ceded the initial land allocations to them. They were reluctant, however, to give additional land to resettled villages, unless the resettlement villages were to grant them the political superiority to which this loan of land should entitle them under existing cultural norms. Precisely for this reason, many resettlement villages, who saw themselves as the most prominent in the Bafing, were reluctant to ask formally for more land from their hosts, as this would indicate acceptance of a subordinate position. ${ }^{16}$

Not only did local political considerations limit the ease with which farmers could expand cultivated areas, but so too did national ones. PRM-drawn maps, delineating only the initial allocations, tended to rigidify boundaries. The local administration, host villages, and relocatees all began to see the maps as a sort of "cadastre" delimiting their lands, despite their lack of formal legal status. When adjacent villages brought land disputes to the arrondissement, administrators often referred to the maps in resolving them.

The end result of these disparate factors was that people did not have enough land to meet their new agricultural goals using the pre-resettlement bush fallow system. They could nevertheless have moved to more continuous cultivation, had they been able to intensify sustainably their agricultural practices. Here is where structural adjustment had its most important impact, primarily through its role in decreasing access to agricultural inputs. $^{17}$

As discussed above, decreased funding for ODIPAC required it to drop certain activities and lay off personnel, weakening its presence, even though it did not disappear until 1996. Because people found it very difficult to get purchased inputs, use of them was extremely low by 1993-94. ${ }^{18}$ In our sample, only two collective field owners and two male owners of individual fields had used chemical fertilizers. In addition, one collective field owner had purchased fungicide and another had bought pesticides; one male individual

16. For further information on land access strategies and their local sociopolitical implications, see D.Koenig and T.Diarra (1998). 
field owner had purchased fungicide. No women had purchased manufactured inputs. Even one farmer viewed by ODIPAC as one of the most willing to follow extension advice properly had stopped using fertilizers. Users not only had to buy these inputs for cash, but they had to go some distance to get them. One of the few users had gone to Bamako, the capital, $300 \mathrm{~km}$ distant, a strategy out of the reach of most Bafing residents.

Lack of agricultural inputs played a substantial role in creating the negative environmental effects. With decreased access to inputs but greater ease in purchasing and using machinery, farmers used equipment to extend land areas rather than to intensify production, as they have done in many areas where land was abundant. Many farmers explicitly told us that with increased equipment use, they needed more land than they had in the old sites. Women were particularly eloquent about their desires for more land so that they could grow and sell more peanuts.

The situation was ripe for examining alternatives to agricultural chemicals, but no agencies stepped in on any significant scale to work with farmers on organic strategies. Peace Corps volunteers taught soil conservation techniques in a few villages, and at various times the Forestry Service attempted to offer advice about agroforestry. Farmers appeared to be willing to try nonchemical means to increase soil fertility, but neither the public nor the private sector offered sufficient information or incentives. Initiatives of this type appear to require well-funded, broad-based educational efforts. These did not exist, in part because structural adjustment's emphasis on the private sector discouraged public sector involvement in solving these problems, despite the Malian government's policy focus on conservation. Lacking funds to carry out positive programs, many national efforts were restricted to policing activities. ${ }^{19}$ Hence, by 1993-4, most farmers had extremely little choice about how to maintain soil fertility. Long fallows requiring substantial amounts of land had become the only realistic option. When economic opportunities led them to want more land, farmers also needed more land for ecological reasons.

17. The potential effects of structural adjustment were not foreseen by the resettlement design team, who had made plans as if ODIPAC would continue to exist as it had in the past. The agricultural analysis noted that the World Bank, which had funded ODIPAC for many years, was encouraging it to pursue new directions, primarily a greater orientation to local conditions and markets (USAID 1984, Annex 7.6:3). In that context, the institutional analysis suggested giving ODIPAC a key role in post-resettlement plans for procurement, storage, transport, and distribution of agricultural inputs (USAID 1984, Annex 7.5:23). Even in the late 1980s, monitoring reports encouraged the PRM to work more closely with ODIPAC on post-resettlement activities, given the important role that this organization had held (D.Koenig 1988a).

18. Theoretically, lack of access to credit could also be a bottleneck. Local villagers enthusiastically created Associations Villageois, however, a new vehicle to get group credit from private banks. Many had in fact received credit, although some could not pay it back because they could not increase production due to land fertility problems. Nevertheless, at the time of the study, credit access was a less significant problem than input and land access.

19. Despite structural adjustment, some European donors, especially Germany and the Netherlands, continued to finance environmental conservation projects in other parts of Mali. They were not active in Manantali in the early 1990s. 


\section{Responses to the New Policy Environment}

Unlike the rural development efforts of the 1970s, which offered additional options but did not close off old ones, the policy initiatives of the late 1980s closed off existing options. The resettlement project changed the proximate natural environment, creating greater resource pressure and decreasing the diversity of natural resources through increased population density and land clearing. Structural adjustment programs took away guaranteed crop sales and easy access to agricultural inputs. Manantali residents tried to confront the new context as best they could, but met with unanticipated results.

People were clear that the new context meant declining land productivity. Although they were quite enthusiastic about productivity in 1989, when they had just moved to lands mostly uncultivated for a long time, they were pessimistic by 1993-94. Average peanut yields had fallen from $1,107 \mathrm{~kg} / \mathrm{ha}$ in $1988-89$ to $900 \mathrm{~kg} / \mathrm{ha}$ in 1993-94; millet yields had fallen from $934 \mathrm{~kg} / \mathrm{ha}$ to $700 \mathrm{~kg} / \mathrm{ha}$ during the same period. ${ }^{20}$ In part this was due to lower rainfall in the latter season (only $702 \mathrm{~mm}$ in 1993-4 compared to 1,091 mm in 1988-89), but people also pointed to a trend of decreasing yields. They explicitly stated that they were using land with little fallow and with few inputs, organic or purchased, to improve their soils. For locals, the most obvious evidence of decreasing soil fertility was what they called sege in Malinke. This term, translated as potash, referred both to concentrations of potash in the soil and to the presence of Striga, a parasitic weed often attributed to lack of fertility.

People also appeared to be aware that the economic growth brought by structural adjustment and resettlement exacerbated land pressure when they tried to increase production with fewer inputs and less easy access to land. Although many tried to deal with problems by changing crop mixes, there was no outside support for new crops (e.g., access to improved seed varieties, or technical information about them). Many saw their move into new commercial activities as an addition to, rather than a substitute for, agriculture. This solved neither land shortages nor fertility problems, especially since many of the local commercial activities (e.g., crop sales, food processing, peanut thresher production) grew from the agricultural base. Thrown upon their own resources, most tried to solve soil fertility problems by the means they already knew best, increasing the amount of land under cultivation so that they could sustainably continue shifting or bush-fallow cultivation.

As most (65\%) had already cleared and cultivated all the land allocated by the PRM, they looked for new land. Despite the political problems involved in clearing new lands, 88 percent (100 of 113) of sample households had augmented their initial allocations. Because people did not measure land areas either before or after the resettlement, it is impossible to know the amount of new land cleared. Anecdotal evidence suggests that it was substantial, at least 50 percent of that cleared by the resettlement project. Some returned to old fields or hamlets that had not been flooded upstream from the dam, whereas others created new hamlets on nearby plateaux. As some residents moved to new areas, other residents took over their fields within the village. Although people tried to get land near their new villages, many, if not most, had to go significant distances. ${ }^{21}$

20. Both sets of yield figures were collected through the placement of yield squares by the same ODIPAC agent.

21. There were no instances of either land sales or rentals, despite the perceived land shortages. 
The search for new land increased the environmental effects as people cut forests or took over existing pasture, putting increased stress on these resources. Because the tenure of newly cleared areas was problematic, people tended to wait until the fertility of their fields was seriously compromised before moving on. This was reflected in their conscious anxiety about getting new land, as people compared a situation in the old sites where fallows and hamlets were in "their own territory" vs. the new situation where they more often had to clear new fields or make hamlets on "somebody else's" land. This mining of the soil until most fertility has been exhausted has been found as well in other areas where land is scarce or tenure insecure (D.McMillan et al. 1998).

The choice between economic benefits and ecological possibilities had social costs. Those who chose to remain in the resettlement villages often tried to clear more land on the village borders, leading to conflict with existing host villages who claimed this land. Although people often got permission to clear new fields, either through individual loans (32 of 100) or through permission of the chief whose village held the land (22 of 100), more than a quarter (26 of 100) had cleared without asking anyone's authorization. As one individual said, the PRM had told them that there was almost no one between the new villages and Mahina to the north, so they just cleared. Disputes over land were common; many were acrimonious although few were violent.

Some chose to avoid conflict by moving far away to a seasonal hamlet, but to move an entire household to a hamlet meant that the head had to face the loss of social identity and privilege linked to living in his own village. The chief of one village kept his title, but lost much of his power when he moved to a hamlet, because another member of his lineage took over the day-to-day responsibilities of the position. Large households had the option to split their membership, keeping some in the village and sending others to hamlets, but this dispersed the labor force, and these households lost some of the economies of scale that accrued to large families.

Villagers also noted that the greater density of settlement allowed increased communication among them, creating the context for more effective political associations. They had used their ability to organize to confront and negotiate with the local administration, yet postresettlement land shortages risked dispersing this new-found political force when villages lost population. Even though resettlement planners had tried hard to avoid the social disintegration that so often haunts resettlement by including strategies to increase social cohesion, many households and villages later found they had to split to assure economic survival.

By 1993-94, residents believed they had to choose between what they saw as the economic benefits that came from the resettlement and privatization (access to better roads, more infrastructure such as schools, health clinics, and markets, and more diverse nonagricultural opportunities) and the ability to have sufficient land to carry out a sustainable agricultural system. The former strategy required them to stay close to roads and in densely populated villages, whereas getting sufficient land often meant a move to hamlets at a significant distance from new villages. People did not speak of this move as a positive choice, but one that environmental problems in the new sites had forced them to undertake. The move to hamlets was especially strong among the villages with the most severe land shortage problems. 


\section{Conclusions}

Although many have pointed to the dangers of greater reliance on commercial production, we must agree with the residents of Manantali: privatization and greater commercialization brought clear economic benefits. These included more jobs and more opportunities to sell local produce and goods. In addition, the improved access to commercial activities broke the dominance of the few large merchants who had monopolized commerce prior to the resettlement. Better market structures allowed residents to meet food deficits more easily, because they could buy food. Yet the economic benefits came with negative environmental consequences because these policy interventions led to land shortages and decreased access to the means to intensify production and maintain soil fertility. Individual and household survival came at the expense of the regional land resource base. Although some individuals and families dealt with the economic aspects of declining land fertility by turning to nonagricultural options, they rarely used income generated in this way to invest in land fertility, in part because there were few agricultural inputs that could be bought locally. The combined effects of simultaneous resettlement and structural adjustment caused greater environmental problems than might have occurred had either policy been implemented alone. Together these well-funded efforts, supported by major donors, overwhelmed national efforts at land and soil conservation.

It was difficult to foresee the consequences of these coexisting policies, because analyses of both theory and practice have not taken their interactions sufficiently into account. Most recent theories emphasize the homogeneity of state interests and concerns, masking their complicated interplay. Yet neither the multiple policies pursued by the national government nor the constraints imposed by international donors were seamless. They could be inconsistent or even contradictory. New agendas and fashions came into vogue, not always displacing the old ones and their projects. Different institutions worked with different priorities, sometimes under the influence of different development agendas. This was not new; many Malian farmers had stories of agricultural agents who encouraged them to uproot trees so that they could plant in rows at the same time that forestry service agents were encouraging agroforestry strategies that kept the trees in the fields. We need more empirical studies of governmental activities as well as their results if we are to understand the complex effects on local people.

At the level of practice, this case suggests that planners, who typically focus on one policy initiative at a time, need to look more directly at the potential effects of other programs, which may either strengthen or negate their own development goals. In the case of Manantali, those planning the resettlement project were naive in their supposition that the Malian policy terrain would remain stable over the period of the project, and they underestimated the far-reaching impacts that structural adjustment programs would have. Excellent work has recently been done to elucidate the connection between resettlement plans and their outcomes (e.g., M.Cernea 1996), but there is little reference to national and international policy environments. If the interaction of various policy contexts made a difference in this case, it likely has been important in others as well.

Despite the problems caused by interacting policy interventions, this case study, perhaps somewhat paradoxically, calls into question recent critiques of the state that have come from both the left and the right (M.Watts 1983). Whereas liberal thinkers have looked to the market to solve the problems, more radical ones have proposed a central role for grassroots associations and locally generated social movements. In this case study, the 
interaction of two policy interventions demonstrated the inability of the market to regulate sufficiently all aspects of the economy, particularly in a situation such as this where markets, although more open than before, remained relatively small and transport constraints high. Long-term sustainability, in both the economic and environmental sense, cannot be increased unless attention is paid simultaneously to markets, farmer income, and land fertility. Farmers who can grow high-value crops often may be more willing to invest in their land, but they also need access to the resources to do so.

Here, farmers were able to sustain income streams in the face of adverse environmental conditions but at the cost of environmental sustainability. Although the economic benefits brought by dam construction, resettlement, and structural adjustment helped Manantali farmers, long-term land fertility suffered. Yet, more rather than less planning and intervention, based on a multifactor analysis of the effects of existing policies, were needed. In particular, interventions to support alternative efforts to increase land fertility and to facilitate the development of local sales of conventional agricultural inputs were needed. People also needed more information about new options, as well as more support for new local initiatives with positive results. For example, a partnership of interested farmers with agricultural research teams might improve results for those who tried experiments such as cultivating trees that formerly grew wild. If local vendors could learn about agricultural input sources, they might more easily enter fertilizer sales.

This study also suggests that local social movements and associations might benefit from a more comprehensive understanding of the complexity of national and international policy contexts. Local participation, which can give a group ownership of development initiatives, is obviously important, but this study suggests that local grassroots initiatives and participation often provide too narrow a framework to counter the negative effects of national or international policies. This is especially true given the inconsistent or even contradictory nature of many simultaneously implemented initiatives. Local participation can only be effective when complemented by appropriate knowledge and information about regional, national, and international policy processes.

\section{References Cited}

Adu-Aryee, V.Q.

1993. Resettlement in Ghana: From Akosombo to Kpong. In Anthropological Approaches to Resettlement: Policy, Practice, and Theory. M. Cernea and S. Guggenheim, editors. Boulder, CO: Westview. Pp. 133-151.

Bayart, Jean-François.

1995. Réflexions sur la politique africaine de la France. Politique Africaine 58:41-50.

Bingen, R. James, Brent Simpson, and Adama Berthé.

1993. Analysis of Service Delivery Systems to Farmers and Village Associations in the Zone of the Office de la Haute Vallée du Niger. East Lansing, MI: Michigan State University Dept. of Resource Development.

Brasseur, Gerard.

1968. Les établissements humains au Mali. Memoire de l'Institut Fondamental d'Afrique Noire (IFAN) Number 83. Dakar: IFAN.

Bratton, Michael and Nicolas van de Walle. 
1992. Toward Governance in Africa: Popular Demands and State Responses. In Governance and Politics in Africa. G. Hyden and M. Bratton, editors. Boulder, CO: Lynne Rienner. Pp. 27-55.

Cernea, Michael.

1988. Involuntary Resettlement in Development Projects: Policy Guidelines in World Bank-Financed Projects. World Bank Technical Paper Number 80. Washington, DC: The World Bank.

1991. The Social Actors of Participatory Afforestation Strategies. In Putting People First: Sociological Variables in Rural Development. M. Cernea, editor. New York: Oxford University Press for the World Bank. Pp. 340-393.

1996. Eight Main Risks: Impoverishment and Social Justice in Resettlement. Washington, DC: The World Bank, Environment Department.

Charest, Paul.

1982. Hydroelectric Dam Construction and the Foraging Activities of Eastern Quebec Montagnais. In Politics and History in Band Societies. E. Leacock and R. Lee, editors. Cambridge: Cambridge University Press. Pp. 413-426.

Chazan, Naomi.

1992. Liberalization, Governance, and Political Space in Ghana. In Governance and Politics in Africa. G. Hyden and M. Bratton, editors. Boulder, CO: Lynne Rienner. Pp. 121-141.

Colson, Elizabeth.

1971. The Social Consequences of Resettlement. Manchester: Manchester University Press.

Coquery-Vidrovitch, Catherine.

1986. French Black Africa. In The Cambridge History of Africa. Vol. 7, from 1905 to 1940. A.D. Roberts, editor. Cambridge: Cambridge University Press. Pp. 329-398.

Diarra, Tiéman, Dolores Koenig, Yaouaga Félix Koné, and Fatoumata Maiga.

1995. Réinstallation et développement dans la zone du barrage du Manantali. Bamako: Institut des Sciences Humaines.

DNAS (Direction Nationale des Affaires Sociales).

1985. Enquêtes sur les populations déplacées du fait de la sécheresse. Bamako: DNAS.

DNEF (Direction Nationale des Eaux et Forêts).

1986. Textes forestières. Bamako: Imprimerie Nouvelle.

Due, Jean.

1991. Policies to Overcome the Negative Effects of Structural Adjustment Programs on African Female-Headed Households. In Structural Adjustment and African Women Farmers. C. Gladwin, editor. Gainesville, FL: U. of Florida Press. Pp. 103127.

Duncan, Alex and John Howell.

1992. Introduction: Assessing the Impact of Structural Adjustment and Conclusions: Beyond Adjustment. In Structural Adjustment and the African Farmer. A. Duncan and J. Howell, editors. London: Overseas Development Institute with James Currey. Pp. 1-13 and 199-208.

Ensminger, Jean. 
1991. Structural Transformation and Its Consequences for Orma Women Pastoralists. In Structural Adjustment and African Women Farmers. C. Gladwin, editor. Gainesville, FL: U. of Florida Press. Pp. 281-300.

Fofana, Makan, Halimata Konaté Simaga, and Dolores Koenig.

1992. Rapport de site: Selingue. Mimeo. Report to Institute for Development Anthropology for Land Settlement Review.

Gladwin, Christina.

1991. Fertilizer Subsidy Removal Programs and Their PotentialImpacts on Women Farmers in Malawi and Cameroon. In Structural Adjustment and African Women Farmers. C. Gladwin, editor. Gainesville, FL: University of Florida Press. Pp. 191216.

1995. Comparing Ethnographic Methods to Assess the Impacts of Structural Adjustment Policies. Paper presented at the Meetings of the American Anthropological Association. November 15-19, Washington, DC.

Godana, Boyana Adhi

1985. Africa's Shared Water Resources: Legal and Institutional Aspects of the Nile, Niger and Senegal River Systems. Boulder, CO: Lynne Rienner.

Greenberg, James.

1997. A Political Ecology of Structural-Adjustment Policies. Culture and Agriculture 19(3):85-93.

Grimm, Curt.

1991. Turmoil and Transformation: A Study of Population Relocation at Manantali,

Mali. Ph.D. Dissertation, Department of Anthropology, SUNY Binghamton.

GRM (République du Mali).

1987. Code domanial et foncier. Bamako.

Groupement Manantali.

1978. Etude d'exécution du barrage et de l'usine hydroélectrique de Manantali. Rapport final. Mission A.1.14 Recasement des populations. Report to the OMVS.

Guyer, Jane with Olukemi Idowu.

1991. Women's Agricultural Work in a Multimodal Rural Economy: Ibarapa District, Oyo State, Nigeria. In Structural Adjustment and African Women Farmers. C. Gladwin, editor. Pp. 257-280.

Hall, Anthony.

1994. Grassroots Action for Resettlement Planning: Brazil and Beyond. World Development 22:1793-1809.

Horowitz, Michael, Dolores Koenig, Curt Grimm, and Yacouba Konate.

1993. Resettlement at Manantali, Mali: Short-term Success, Long-term Problems. In Anthropological Approaches to Resettlement: Policy, Practice, and Theory. M. Cernea and S. Guggenheim, editors. Boulder, CO: Westview. Pp. 229-250.

IER (Institut d'Economie Rurale).

1984. Récasement des Populations de Manantali: Etude Agro-Socio-Economique. Bamako: Institut d'Economie Rurale.

Jones, William I.

1976. Planning and Economic Policy: Socialist Mali and Her Neighbors. Washington,

DC: Three Continents Press.

Kamuanga, Mulumba. 
1982. Farm Level Study of the Rice Production System at the Office du Niger in Mali: An Economic Analysis. Ph.D. dissertation, Department of Agricultural Economics, Michigan State University.

Kebé, Youssouf Gaye.

1981. L'agriculture malienne, le paysan, sa terre et l'état. In Le Mali: Le paysan et l'état. P. Jacquemot, editor. Paris: Harmattan. Pp. 21-102.

Koenig, Dolores.

1986. Research for Rural Development: Experiences of an Anthropologist in Rural Mali. In Anthropology and Rural Development in West Africa. M. Horowitz and T. Painter, editors. Boulder, CO: Westview. Pp. 27-60.

1988a. The Manantali Resettlement Project: One Year after Resettlement. Report to USAID. Binghamton, NY: Institute for Development Anthropology.

1988b. Local Politics and Resettlement in Manantali, Mali. Paper presented at the meetings of the African Studies Association. October, Chicago.

1997. Competition among Malian Elites in the Manantali Resettlement Project: The Impacts on Local Development. Urban Anthropology and Studies of Cultural Systems and World Economic Development 26(3-4):369-411.

Koenig, Dolores, Fatoumata Maiga, and Sira Traoré.

1995. Changing Labor Strategies in the 1990s: Gender Roles in Manantali, Mali. Paper presented at the meetings of the African Studies Association. November 3-6, Orlando, FL.

Koenig, Dolores and Tiéman Diarra.

1996. The Effects of Resettlement on Access to Common Property Resources. Paper presented at the Conference on Reconstructing Livelihoods, Refugee Studies Programme, University of Oxford. September 9-12, Oxford.

1998. Les enjeux de la politique locale dans la réinstallation: Stratégies foncières des populations réinstallées et $h_{c}$ tes dans la zone du barrage de Manantali, Mali. Autrepart (Cahiers dessciences humaines), Nouvelle série 5:29-44.

Konate, Yacouba.

1993. Resettlement in Manantali, Mali: A View from Inside. Paper presented at the meetings of the American Anthropological Association. November 17-21, Washington, DC.

Lassailly-Jacob, Véronique.

1996. Land-Based Strategies in Dam-Related Resettlement Programmes in Africa. In Understanding Impoverishment: The Consequences of Development-Induced Displacement. C. McDowell, editor. Oxford: Berghahn.

McConnell, William, Dolores Koenig, Jean-Michel Jolly, David Midgarden, and Suzanne Piriou.

1994. Opportunities for Success in Integrated Pest Management: Socioeconomic Conditions of Farmers in Mali. Washington, DC: USAID.

McMillan, Della, John Sanders, Dolores Koenig, Kofi Akwabi-Ameyaw, and Thomas Painter.

1998. New Land is Not Enough: Agricultural Performance of New Lands Settlement in West Africa. World Development 26(2):187-211. 
Mustanoja, Ulla-Marjatta and Kari Mustanoja.

1993. Resettlement after Involuntary Displacement: The Karelians in Finland. In Anthropological Approaches to Resettlement: Policy, Practice, and Theory. M. Cernea and S. Guggenheim, editors. Boulder, CO: Westview. Pp. 87-107.

O'Brien, Stephen.

1991. Structural Adjustment and Structural Transformation in Sub-Saharan Africa. In Structural Adjustment and African Women Farmers. C. Gladwin, editor. Gainesville: University of Florida Press. Pp. 25-45.

PIRT (Projet Inventaire des Ressources Terrestres). 1986. Zonage agro-écologique du Mali. Bamako:PIRT.

Reardon, Thomas, Valerie Kelly, Bocar Diagana, Josué Dioné, Eric Crawford, Kimseyinga Savadogo, and Duncan Broughton.

1995. Capital-led Intensification in Sahel Agriculture: Addressing Structural Constraints after Macroeconomic Policy Reform. Paper presented at the meetings of the American Anthropological Association. November 15-19, Washington, DC.

Richards, Paul.

1983. Ecological Change and the Politics of African Land Use. African Studies Review 26(2):1-72.

Robinson, David.

1985. The Holy War of Umar Tal: The Western Sudan in the Mid-Nineteenth Century. Oxford: Clarendon Press.

Robinson, Kathryn.

1986. Stepchildren of Progress: The Political Economy of Development in an Indonesian Mining Town. Albany, NY: SUNY Press.

Samaké, Maximin, Moussa Sow, Mamadou Sarr, Fatoumata Maiga, and Baba Camara.

1986. Etude de l'économie domestique dans la zone du barrage de Manantali. Phase II. Bamako: Institut des Sciences Humaines.

1987. Etude de l'économie domestique dans la zone du barrage de Manantali. Phase III. Bamako: Institut des Sciences Humaines.

SATEC (Sodeteg Aide Technique pour la Cooperation et le Développement).

1984, 1985. Etude des opérations de développement rural (ODR) et des organismes similaires. Vol 1: Missions, fonctions, statuts juridiques, gestion administrative et financière, zones d'interventions (September 1984). Vol 2: Methods et dispositifs d'intervention; Transfert des activités; Besoins en moyens humains, en materiels et en fonction (November 1984). Vol 3: Propositions de redressement (January 1985). Synthèse. Paris and Bamako: SATEC and Ministry of Plan.

Scudder, Thayer.

1981. The Development Potential of New Lands Settlement in the Tropics and Subtropics: A Global State of the Art Evaluation with Specific Emphasis on Policy Implications. Binghamton, NY: Institute for Development Anthropology.

1991. A Sociological Framework for the Analysis of New Land Settlements. In Putting People First: Sociological Variables in Rural Development. M. Cernea, editor. New York: Oxford University Press for the World Bank. Pp. 148-187.

Somerville, Carolyn.

1986. Drought and Aid in the Sahel: A Decade of Development Cooperation. Boulder, CO: Westview.

Steedman, Charles, Thomas Daves, Marlin Johnson and John Sutter. 
1976. Mali Agricultural Assessment. Ann Arbor, MI: University of Michigan Center for Research on Economic Development.

TAMS (Tippetts-Abbett-McCarthy-Stratton).

1983. Les ressources terrestres au Mali. Vol. 2, Rapport technique. Bamako: Ministère Chargé du Développement Rural.

Traoré, Adama Moussa.

1995. Les enjeux de la gestion de l'espace dans la zone de Manantali: Réalités et perspectives. Thèse de doctorat, Institut Supérieur de Formation et de Recherche Appliquée, Bamako.

Traoré, Mamadou, editor.

1980. Atlas du Mali. Paris: Editions Jeune Afrique.

USAID (United States Agency for International Development).

1984. Project Paper: Mali, Manantali Resettlement. Washington, DC: USAID.

van Campen, Wim, Jan Hijkoop, and Piet van der Poel.

1988. D'un aménagement anti-érosif des champs à la gestion de l'espace rurale.

Bamako: CMDT, Institut d'Economie Rurale et Institut Royal des Régions Tropicales, Amsterdam.

Wali, Alaka.

1993. The Transformation of a Frontier: State and Regional Relationships in Panama, 1979-1990. Human Organization 52:115-129.

Watts, Michael.

1983. "Good Try, Mr. Paul": Populism and the Politics of African Land Use. African Studies Review 26(2):73-83.

Wilcock, David.

1995. Cereals Marketing Policy Reform in Three African Countries: Vested Interests, Marketing Efficiency, and Food Security. Paper presented at the meetings of the American Anthropological Association. November 15-19, Washington, DC.

World Bank.

1981. Accelerated Development in Sub-Saharan Africa: An Agenda for Action. Washington, DC: World Bank.

1989. Sub-Saharan Africa: From Crisis to Sustainable Growth. Washington, DC: The World Bank.

1994. Programme de la Coopération Mali-Banque Mondiale. Bamako: Mission Residente de la Banque Mondiale au Mali.

Wrigley, C.C.

1986. Aspects of Economic History. In The Cambridge History of Africa. Vol. 7, from

1905 to 1940. A.D. Roberts, editor. Cambridge: Cambridge University Press. Pp. 77-139.

\section{Abstract}

This article broadens analytic perspectives on the effects of government interventions by looking at the interaction of two distinct but simultaneous policy initiatives: involuntary resettlement and structural adjustment. Case study data from the Bafing valley in Mali 
show that simultaneous implementation of these two initiatives reinforced the economic growth of the zone but increased negative environmental effects.

Key Words: Mali, resettlement, structural adjustment, sahel, environmental degradation, economic development, river basin development, privatization, liberalization.

\section{Resumé}

Cet article élarge les perspectives analytiques des effets d'une intervention gouvernementale à partir d'une examination de l'interaction de deux politiques distinctes mais simultanées: le repeuplement involontaire et l'ajustement structural. L'étude des données du vallée de Bafing au Mali montre que l'implementation simultanée de ces deux initiatives a renforcé et la croissance économique de la zone et les effets négatifs environnementaux.

Mots clefs: Mali, repeuplement, ajustement structural, sahel, dégradation environnementale, développement économique, développement des bassins fluviaux. privatisation, libéralisation.

\section{Resumen}

Este artículo amplifica la perspectiva analítica sobre los efectos de intervenciones gubernamentales comenzando por examinar la interacciín de dos iniciativas de normas diferentes pero simultáneas: el restablecimiento involuntario y el ajuste estructural. Datos derivados de estudios de casos del valle Bafing en Mali muestra que la implementación simultanea de estas dos iniciativas reforzó el crecimiento económico de la zona, pero aumentó los efectos negativas en el medio ambiente.

Palabras claves: Mali, restablecimiento, ajuste estructural, sahel, degradación ambiental, desarrollo económico, desarrollo de cuencas, privatización, liberalización. 